\begin{tabular}{|c|c|c|}
\hline \multirow{3}{*}{$\begin{array}{l}\text { Cellular Physiology } \\
\text { and Biochemistry }\end{array}$} & \multicolumn{2}{|c|}{ Cell Physiol Biochem 2016;40:874-882 } \\
\hline & $\begin{array}{l}\text { DOI: 10.1159/000453146 } \\
\text { Published online: December 07, } 2016 \\
\text { Accepted: November 14, } 2016\end{array}$ & $\begin{array}{l}\text { (c) } 2016 \text { The Author(s) } \\
\text { Published by S. Karger AG, Basel } \\
\text { www.karger.com/cpb }\end{array}$ \\
\hline & $\begin{array}{l}\text { This article is licensed under the Creative } \\
\text { tional License (CC BY-NC-ND) (http://ww } \\
\text { for commercial purposes as well as any dis }\end{array}$ & $\begin{array}{l}\text {-NonCommercial-NoDerivatives } 4.0 \text { Inte } \\
\text { DpenAccessLicense). Usage and distribu } \\
\text { naterial requires written permission. }\end{array}$ \\
\hline
\end{tabular}

\title{
$\beta$-Klotho as a Negative Regulator of the Peptide Transporters PEPT1 and PEPT2
}

\author{
Abeer Abousaaba Jamshed Warsia, ${ }^{a}$ Madhuri S. Salker ${ }^{a}$ Florian Langa,c \\ aDepartment of Cardiology, Vascular Medicine and Physiology, University of Tuebingen, Tuebingen, \\ Germany; ${ }^{b}$ Department of Physiology, University of Sindh, Jamshoro, Pakistan; 'Department of \\ Molecular Medicine II, Heinrich Heine University Duesseldorf, Duesseldorf Germany
}

\section{Key Words}

$\mathrm{PEPT} 1 \cdot \mathrm{PEPT} 2 \cdot \mathrm{DSAL} \cdot$ Glycine-glycine $\bullet \beta$-glucuronidase $\bullet$ Ageing $・$ Intestine

\begin{abstract}
Background/Aims: $\beta$-Klotho, a transmembrane protein expressed in several tissues including the brain and the kidney, is critically important for inhibition of $1,25(\mathrm{OH})_{2} \mathrm{D}_{3}$ formation by FGF23. The extracellular domain of Klotho protein could be cleaved off, thus being released into blood or cerebrospinal fluid. Soluble klotho is a $\beta$-glucuronidase participating in the regulation of several ion channels and carriers. The present study explored the effect of $\beta$-Klotho protein on the peptide transporters PEPT1 and PEPT2. Methods: CRNA encoding PEPT1 or PEPT2 was injected into Xenopus laevis oocytes and glycine-glycine $(2 \mathrm{mM})$-induced inward current $\left(\mathrm{I}_{\text {Gly }}\right)$ taken as measure of glycine-glycine transport. Measurements were made without or with prior $24 \mathrm{~h}$ treatment with soluble $\beta$-Klotho protein $(30 \mathrm{ng} / \mathrm{ml})$ in the absence and presence of $\beta$-glucuronidase inhibitor D-saccharic acid 1,4-lactone monohydrate (DSAL,10 $\mu \mathrm{M})$. Ussing chamber experiments were employed to determine electrogenic peptide transport across intestinal epithelia of klotho deficient $\left(\mathrm{kl}^{-/}\right)$and corresponding wild type $\left(\mathrm{kl}^{+/+}\right)$mice. Results: $\mathrm{I}_{\text {Gly }}$ was observed in PEPT1 and in PEPT2 expressing oocytes but not in water injected oocytes. In both, PEPT1 and PEPT2 expressing oocytes $\mathrm{I}_{\text {GIy }}$ was significantly decreased by treatment with soluble $\beta$-Klotho protein. As shown for PEPT1, $\beta$-klotho protein decreased significantly the maximal transport rate without significantly modifying the affinity of the carrier. The effect of $\beta$-Klotho on PEPT1 was reversed by DSAL. Intestinal $\mathrm{I}_{\text {Gly }}$ was significantly larger in $\mathrm{kl}^{-/-}$than in $\mathrm{kl}^{+/+}$mice. Conclusion: $\beta$-Klotho participates in the regulation of the peptide transporters PEPT1 and PEPT2.

\section{Introduction}

Klotho is a transmembrane protein expressed in several tissues with particular strong expression in kidney and choroid plexus $[1,2]$. The extracellular domain of the Klotho protein with $\beta$-glucuronidase activity may be cleaved off and released into blood and cerebrospinal

A. Abousaab and J. Warsi contributed equally thus shared the first authorship.

Prof. Dr. Florian Lang

Department of Physiology, University of Tuebingen,

Gmelinstr. 5, D-72076 Tuebingen, (Germany)

Tel. +49 7071/2972194, Fax +49 7071/295618, E-Mail florian.lang@uni-tuebingen.de 
fluid [3-7]. Klotho has a powerful impact on ageing [8, 9]. Klotho deficiency results in severe growth retardation, accelerated appearance of several age related disorders, and dramatic shortening of the life span [9]. Conversely, klotho over-expression extends the life span [9, 10].

Klotho is required for the inhibitory effect of FGF23 on $1 \alpha$-hydroxylase and thus $1,25(\mathrm{OH})_{2} \mathrm{D}_{3}$ formation $[2,8,11-14]$. Effects of $1,25(\mathrm{OH})_{2} \mathrm{D}_{3}$ include stimulation of klotho expression [15] as well as intestinal and renal $\mathrm{Ca}^{2+}$ and phosphate absorption [16, 17]. Klotho deficiency is followed by excessive $1,25(\mathrm{OH})_{2} \mathrm{D}_{3}$ formation $[2,13,14]$ leading to increase of plasma $\mathrm{Ca}^{2+}$ [18] and phosphate [17] concentrations as well as vascular calcification [19]. Besides its effect on $1,25(\mathrm{OH})_{2} \mathrm{D}_{3}$ formation, klotho modifies the function of several transport proteins including $\mathrm{Ca}^{2+}$ channels [20], $\mathrm{Na}^{+}$, phosphate cotransport [4, 21], $\mathrm{Na}^{+} / \mathrm{K}^{+}$ ATPase [22], renal outer medullary $\mathrm{K}^{+}$channels [23], Kv1.3 $\mathrm{K}^{+}$channels [24], KCNQ1/KCNE1 [25], the creatine transporter CreaT [26], and the excitatory amino acid transporters EAAT1, EAAT2, EAAT3 and EAAT4 $[27,28]$.

Carriers impacting on ageing include the peptide transporter PEPT1 [32]. Intestinal peptide transport is a major source of nutritional amino acids and is thus decisive for growth and development as well as signaling regulating metabolism and ageing [32]. The possibility was thus considered that klotho may influence peptide transport which in turn may affect ageing.

The present study thus explored, whether Klotho impacts on the function of the peptide transporters 1 (PEPT1) and/or 2 (PEPT2), which accomplish electrogenic cellular uptake of di- and tripeptides [29-31] including peptide-like drugs [30, 31].

\section{Materials and Methods}

\section{Ethical Statement}

All experiments conform with the 'European Convention for the Protection of Vertebrate Animals used for Experimental and other Scientific Purposes' (Council of Europe No 123, Strasbourg 1985) and were conducted according to the German law for the welfare of animals. The surgical procedures on the adult Xenopus laevis frogs were reviewed and approved by the respective government authority of the state Baden-Württemberg (Regierungspräsidium) prior to the start of the study (Anzeige für Organentnahme nach §36).

Constructs

Constructs encoding rabbit wild-type PEPT1 and PEPT2 [33, 34], were used for generation of cRNA as described previously [35, 36].

\section{Voltage clamp in Xenopus oocytes}

Xenopus oocytes were prepared as previously described [37, 38]. Ten ng cRNA encoding PEPT1 or Twenty ng cRNA encoding PEPT2 were injected on the same day after preparation of the oocytes. The oocytes were maintained at $17^{\circ} \mathrm{C}$ in ND96-A, a solution containing (in mM): $88.5 \mathrm{NaCl}, 2 \mathrm{KCl}, 1 \mathrm{MgC} 1_{2}, 1.8$ $\mathrm{CaC1}_{2}, 2.5 \mathrm{NaOH}, 5 \mathrm{HEPES}$ ( $\left.\mathrm{pH} 7.4\right), 5$ sodium pyruvate $\left(\mathrm{C}_{3} \mathrm{H}_{3} \mathrm{NaO}_{3}\right)$, Gentamycin $(100 \mathrm{mg} / \mathrm{l})$, Tetracycline (50 $\mathrm{mg} / \mathrm{l})$, Ciprofloxacin (1.6 mg/l), and Theophiline (90 mg/l) [39, 40]. Where indicated, $30 \mathrm{ng} / \mathrm{ml} ß$-Klotho protein and/or $10 \mu \mathrm{M} \beta$-glucuronidase inhibitor DSAL were added to the respective solutions. The voltage clamp experiments were performed at room temperature 3 days after the first injection of cRNA encoding PEPT1 and 4 days after the injection of PEPT2 [41, 42]. Glycine-glycine induced currents were taken as a measure of glycine-glycine transport $[43,44]$. The holding potential was $-70 \mathrm{mV}$. The data were filtered at 10 $\mathrm{Hz}$ and recorded with a Digidata A/D-D/A converter (1322A Axon Instruments) and Clampex 9.2 software for data acquisition and analysis (Axon Instruments) $[33,45]$. The control superfusate (ND96-B) contained (in mM): $93.5 \mathrm{NaCl}, 2 \mathrm{KCl}, 1.8 \mathrm{CaCl}_{2}, 1 \mathrm{MgCl}_{2}, 2.5 \mathrm{NaOH}$ and 5 HEPES ( $\mathrm{pH} 7.4$ ). The flow rate of the superfusion was approx. $20 \mathrm{ml} / \mathrm{min}$, and a complete exchange of the bath solution was reached within about $10 \mathrm{~s}$ [46, 47]. For kinetic analysis the glycine-glycine induced-current $\left(\mathrm{I}_{\mathrm{Glu}}\right)$ was plotted against the respective glycineglycine concentration $(s)$ and maximal current $\left(\mathrm{I}_{\max }\right)$ as well as concentration required for half maximal current $\left(k_{m}\right)$ calculated using the equation $\mathrm{I}_{\mathrm{Glu}}=\mathrm{I}_{\max } \cdot \mathrm{s} /\left(\mathrm{k}_{\mathrm{m}}+\mathrm{s}\right)$.

\section{KARGER}




\section{Cellular Physiology Cell Physiol Biochem 2016;40:874-882 \begin{tabular}{l|l} 
and Biochemistry Published online: December 07, 2016 & $\begin{array}{l}\text { C } 2016 \text { The Author(s). Published by S. Karger AG, Basel } \\
\text { www.karger.com/cpb }\end{array}$
\end{tabular} \\ Abousaab et al.: Klotho Sensitivity of PEPT1 and PEPT2}

Ussing chamber experiments

All animal experiments were conducted according to the German law for the welfare of animals and according to the guidelines of the American Physiological Society and were approved by local authorities (Regierungspräsidium Tübingen). Experiments were performed using jejunal segments from 6-week old female klotho-deficient mice $\left(\mathrm{kl}^{-}\right)$and wild-type mice. The origin of the mice, breeding and genotyping were described previously [9]. Prior to the experiments mice had access to food (1314, Altromin, Heidenau, Germany) and water ad libitum, and were kept under constant humidity ( $55 \pm 10 \%)$, temperature $\left(22 \pm 2^{\circ} \mathrm{C}\right)$ and $12 \mathrm{~h}$ light-dark cycle conditions. Mice were fasted for 6 hours prior to experiments. Peptide transport rate was estimated from glycine-glycine or from glycine-Sar induced current across the intestinal epithelium. After removing the outer serosal and the muscular layer of jejunum under a microscope, tissues were mounted onto a custom-made mini-Ussing chamber with an opening diameter of $0.99 \mathrm{~mm}$ and an opening area of $0.00769 \mathrm{~cm}^{2}$. Transepithelial potential difference $\left(\mathrm{V}_{\text {te }}\right)$ was determined continuously and transepithelial resistance $\left(R_{\text {te }}\right)$ estimated from the voltage deflections $\left(\Delta V_{\text {te }}\right)$ elicited by imposing rectangular test currents of $1 \mu \mathrm{A}$ and $1.2 \mathrm{~s}$ duration at a rate of $8 / \mathrm{min}$. $\mathrm{R}_{\text {te }}$ was calculated according to Ohm's law [48]. The serosal and luminal perfusate contained (in $\mathrm{mM}$ ): $145 \mathrm{NaCl}, 1 \mathrm{MgCl}_{2}, 2.6$ Ca-gluconate, $0.4 \mathrm{KH}_{2} \mathrm{PO}_{4^{\prime}}, 1.6 \mathrm{~K}_{2} \mathrm{HPO}_{4^{\prime}}$ 5 glucose. To assess peptide transport, glycine-glycine $(10 \mathrm{mM})$ or glycine-Sar $(10 \mathrm{mM})$ was added to the luminal perfusate.

\section{Statistical analysis}

Data are provided as means \pm SEM, $\mathrm{n}$ represents the number of replicates. All voltage clamp experiments were repeated with at least 3 batches of oocytes; in all repetitions qualitatively similar data were obtained. Data were tested for significance using ANOVA or Student's t-test, as appropriate. Results with $p<0.05$ were considered statistically significant.

\section{Results}

The present study explored whether soluble recombinant $\beta$-Klotho protein modifies the electrogenic glycine-glycine transport by the peptide transporters PEPT1 and PEPT2. To this end, PEPT1 or PEPT2 expressing Xenopus laevis oocytes were left untreated or were treated with $\beta$-Klotho protein $(30 \mathrm{ng} / \mathrm{ml})$ and glycine-glycine-induced inward current $\left(\mathrm{I}_{\text {Gly }}\right)$ measured by dual electrode voltage clamp taken as a measure of electrogenic glycine-glycine transport.

\section{Effect of $\beta$-Klotho on PEPT1 in Xenopus laevis oocytes}

As illustrated in Fig. 1, $\mathrm{I}_{\text {Gly }}$ was negligible in water-injected oocytes indicating that the oocytes did not express significant endogenous electrogenic glycine-glycine transport. In contrast, glycine-glycine $(2 \mathrm{mM})$ triggered a sizable $\mathrm{I}_{\mathrm{Gly}}$ in PEPT1 expressing Xenopus laevis oocytes. The treatment of PEPT1 expressing oocytes with $\beta$-Klotho protein $(30 \mathrm{ng} / \mathrm{ml})$ was followed by a significant decrease of $\mathrm{I}_{\text {Gly }}$.

In order to test whether $\beta$-Klotho protein modifies the maximal $\mathrm{I}_{\text {Gly }}$ and/or the affinity of PEPT1, untreated or $\beta$-Klotho protein $(30 \mathrm{ng} / \mathrm{ml})$ treated PEPT1 expressing Xenopus laevis oocytes were exposed to glycine-glycine concentrations ranging from $10 \mu \mathrm{M}$ to $5000 \mu \mathrm{M}$. As illustrated in Fig. 2, $\mathrm{I}_{\text {Gly }}$ was a function of the extracellular glycine-glycine concentration. Maximal $\mathrm{I}_{\text {Gly }}$ was significantly $(p<0.05)$ lower in $\beta$-Klotho protein treated $(44.3 \pm 3.8 \mathrm{nA}, \mathrm{n}=$ $9)$ than in untreated $(62.4 \pm 6.8 \mathrm{nA}, \mathrm{n}=11)$ PEPT1 expressing Xenopus laevis oocytes. The concentration required for half maximal $\mathrm{I}_{\text {Gly }}\left(\right.$ apparent $\mathrm{K}_{\mathrm{m}}$ ) tended to be lower in $\beta$-Klotho protein treated $(367.9 \pm 40.1 \mu \mathrm{M}, \mathrm{n}=9)$ than in untreated $(271.9 \pm 79.9 \mu \mathrm{M}, \mathrm{n}=11)$ PEPT1 expressing Xenopus laevis oocytes, a difference, however, not reaching statistical significance.

A further series of experiments explored whether the effect of $\beta$-Klotho protein is related to its $\beta$-glucuronidase activity. To this end PEPT1 expressing Xenopus laevis oocytes were treated with $\beta$-Klotho protein in the absence and presence of $\beta$-glucuronidase inhibitor D-saccharic acid 1,4-lactone monohydrate (DSAL). As illustrated in Fig. 3, the effect of $\beta$-Klotho protein on electrogenic glycine-glycine transport in PEPT1 expressing Xenopus laevis oocytes was virtually abolished by DSAL $(10 \mu \mathrm{M})$. 
Fig. 1. Effect of recombinant human $\beta$-Klotho protein on electrogenic peptide transport in PEPT1 expressing Xenopus laevis oocytes. A: Representative original tracings of glycine-glycine (2 $\mathrm{mM})$ - induced current $\left(\mathrm{I}_{\mathrm{gly}}\right)$ in Xenopus laevis oocytes injected with water (a) or with cRNA encoding PEPT1 without (b) and with (c) prior $\beta$-Klotho protein $(30 \mathrm{ng} / \mathrm{ml}, 24 \mathrm{~h})$ treatment. B: Arithmetic means \pm SEM $(n=15-17)$ of the normalized glycineglycine $(2 \mathrm{mM})$ - induced current in Xenopus oocytes $\begin{array}{llll}\text { A } & \text { (a) Water } & \text { (b) PEPT1 } & \text { (c) PEPT1+ } \beta \text {-Klotho protein }\end{array}$ injected with water (dotted bar) or expressing PEPT1 without (white bar) or with (black bar) prior $\beta$-Klotho protein $(30 \mathrm{ng} / \mathrm{ml}, 24 \mathrm{~h})$ treatment. Control $\mathrm{I}_{\text {Gly }}$ amounted to $79.8 \pm 6.9 \mathrm{nA}(\mathrm{n}=17) .{ }^{* * *}(p<0.001)$ indicates statistically significant difference from PEPT1 expressing oocytes without $\beta$-Klotho protein treatment.

Fig. 2. Glycine-glycine induced current in PEPT1 expressing Xenopus laevis oocytes as a function of glycine-glycine concentration without and with prior $\beta$-Klotho protein treatment. Arithmetic means \pm SEM $(\mathrm{n}=$ 9-11) of $I_{\text {gly }}$ as a function of glycine-glycine concentration in Xenopus laevis oocytes expressing PEPT1 without (white circles), or with (black squares) prior $\beta$-Klotho protein (30 ng/ml, $24 \mathrm{~h})$ treatment. *** $(p<0.001)$ indicates statistically significant difference from PEPT1 expressing oocytes without $\beta$-Klotho protein treatment.

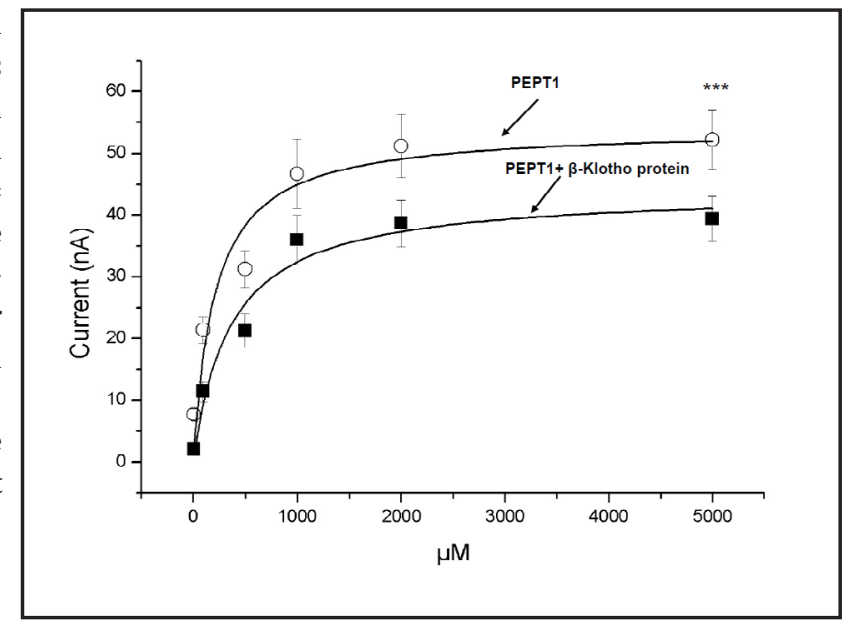

Effect of $\beta$-Klotho on PEPT2 in Xenopus laevis oocytes

An additional series of experiments explored whether klotho was similarly effective in PEPT2 expressing Xenopus laevis oocytes. As illustrated in Fig. 4, glycine-glycine (2 mM) triggered a sizable $\mathrm{I}_{\text {Gly }}$ in PEPT2 expressing Xenopus laevis oocytes. Treatment with $\beta$-Klotho protein $(30 \mathrm{ng} / \mathrm{ml})$ of PEPT2 expressing oocytes was followed by a significant decrease of $\mathrm{I}_{\text {Gly* }}$

In vivo $\beta$-Klotho sensitivity of intestinal peptide transport

In order to test whether klotho sensitivity plays a role in vivo, glycine-glycine (10 $\mathrm{mM})$ induced current was measured in intestinal epithelia utilizing Ussing chambers. As illustrated in Fig. 5, the intestinal glycine-glycine induced current $\left(\mathrm{I}_{\mathrm{Gly}}\right)$ was significantly larger in klotho deficient $\left(\mathrm{kl}^{-/}\right)$mice than in wild-type mice $\left(\mathrm{kl}^{+/+}\right)$. Similar observations were made with the peptide Gly-Sar (Fig. 6) 
Fig. 3. Effect of recombinant human $\beta$-Klotho protein in the absence and presence of $\beta$-glucuronidase inhibitor DSAL on electrogenic glycineglycine transport in PEPT1 expressing Xenopus laevis oocytes. A: Representative original tracings of glycineglycine $(2 \mathrm{mM})$ induced current in Xenopus oocytes injected with cRNA encoding PEPT1 without treatment (a) and with treatment with $\beta$-Klotho protein $(30 \mathrm{ng} / \mathrm{ml}, 24 \mathrm{~h}$ ) alone (b) or together with $\beta$-glu-

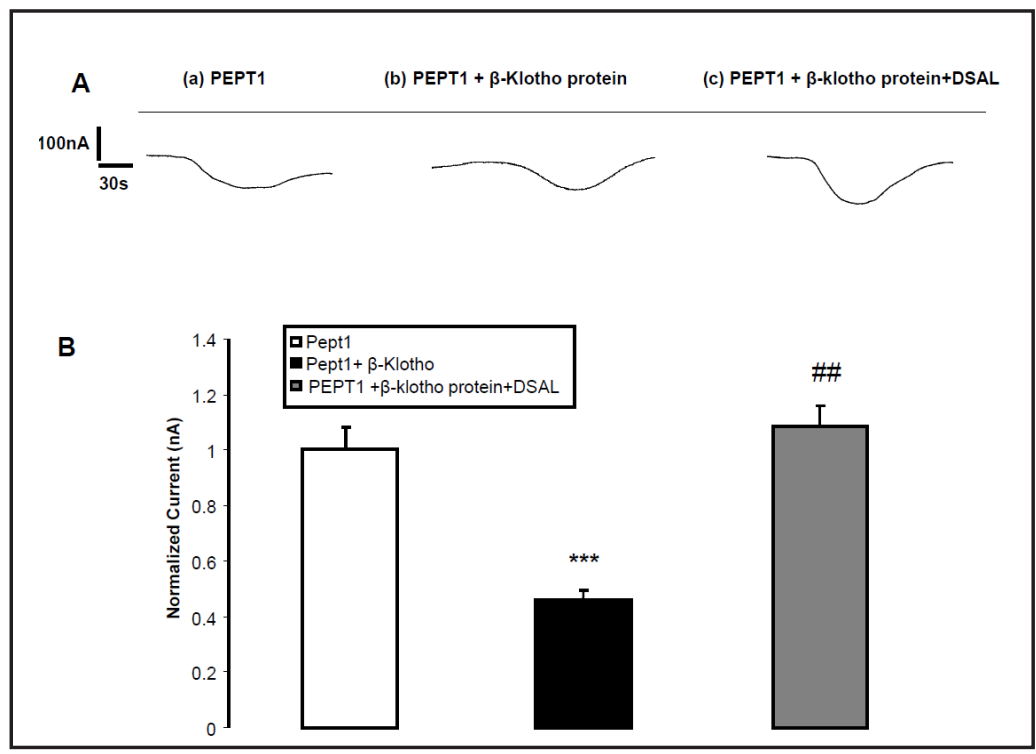
curonidase inhibitor D-saccharic acid 1,4-lactone monohydrate (DSAL,10 $\mu \mathrm{M})(\mathrm{c})$. B: Arithmetic means \pm SEM $(\mathrm{n}=15-20)$ of the normalized glycine-glycine $(2 \mathrm{mM})$ induced current in Xenopus oocytes expressing PEPT1 without treatment (white bar) or with prior $\beta$-Klotho protein $(30 \mathrm{ng} / \mathrm{ml}, 24 \mathrm{~h})$ treatment alone (black bar) or together with $\beta$-glucuronidase inhibitor D-saccharic acid 1,4-lactone monohydrate (DSAL,10 $\mu \mathrm{M}$ ) (grey bar). Control $\mathrm{I}_{\text {Gly }}$ amounted to $53.4 \pm 4.3 \mathrm{nA}(\mathrm{n}=17) .{ }^{* * *}(p<0.001)$ indicates statistically significant difference from respective oocytes without $\beta$-Klotho protein treatment, \#\# $(p<0.01)$ indicates statistically significant difference from respective oocytes without presence of DSAL.

Fig. 4. Effect of recombinant human $\beta$-Klotho protein on electrogenic glycineglycine transport in PEPT2 expressing Xenopus laevis oocytes. A: Representative original tracings of glycineglycine $(2 \mathrm{mM})$ induced current in Xenopus oocytes injected with water (a), or with cRNA encoding PEPT2 without (b) or with (c) prior $\beta$-Klotho protein $(30 \mathrm{ng} / \mathrm{ml}$, $24 \mathrm{~h}$ ) treatment. B: Arithmetic means \pm SEM $(n=12-13)$ of the normalized glycineglycine $(2 \mathrm{mM})$ induced current in Xenopus oocytes

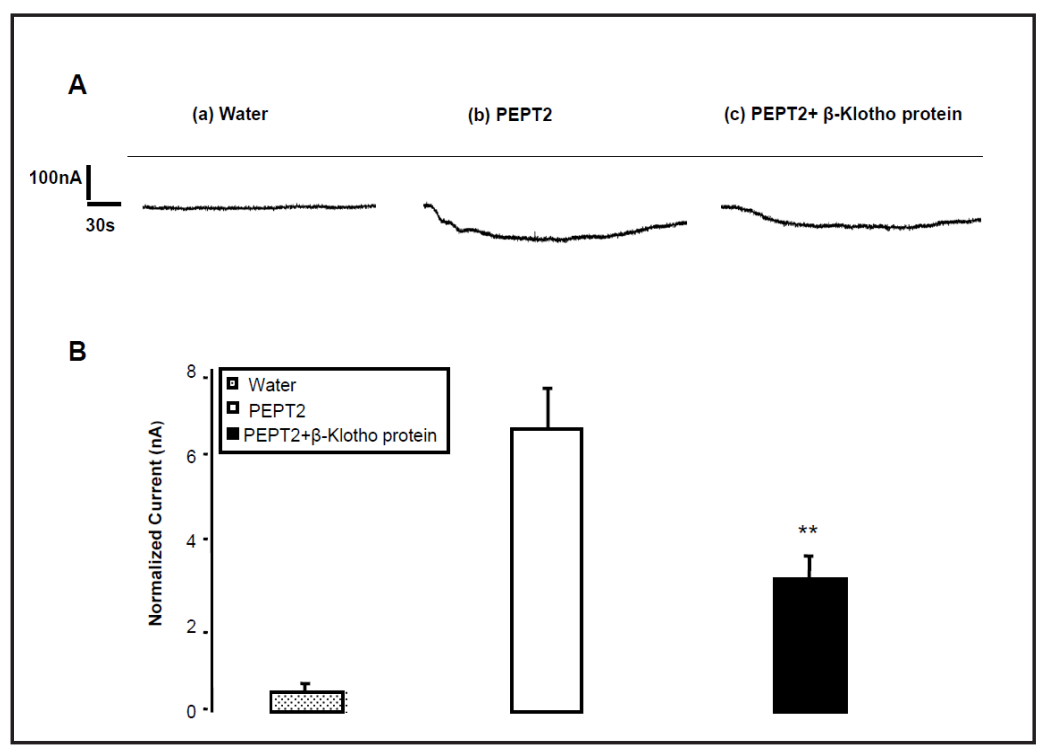
injected water (dotted bar) or expressing PEPT2 without (white bar) or with (black bars) prior $\beta$-Klotho protein $(30 \mathrm{ng} / \mathrm{ml}, 24 \mathrm{~h})$ treatment. ${ }^{* *}(p<0.01)$ indicates statistically significant difference from PEPT2 expressing oocytes without $\beta$-Klotho protein treatment. Control $\mathrm{I}_{\text {Gly }}$ amounted to $70.2 \pm 5.1 \mathrm{nA}(\mathrm{n}=18)$.

\section{Discussion}

The present study uncovers a novel function of $\beta$-Klotho protein, i.e. the down-regulation of the peptide transporters PEPT1 and PEPT2. Treatment of either, PEPT1 and PEPT2 expressing oocytes with human recombinant $\beta$-Klotho significantly decreased the glycine- 
Fig. 5. Glycine-glycine induced transepithelial current in intestinal epithelia from klotho-deficient mice $\left(\mathrm{kl}^{\circ}\right)$ and wild-type $\left(\mathrm{kl}^{+/+}\right)$mice. A. Representative original tracings showing the effect of glycine-glycine (gly-gly) (10 $\mathrm{mM})$ on the transepithelial intestinal potential difference in wild-type mice $\left(\mathrm{kl}^{+/+}\right)$and klotho-deficient mice (right). Arrows highlight the addition of 10 mM glycine-glycine. B. Arithmetic means \pm SEM $(n=4-5)$ of the glycine-glycine $(10 \mathrm{mM})$ induced equivalent short-circuit current across intestinal epithelium from wild-type mice (white bar) and klotho-deficient mice (black bar). ${ }^{*}(p<0.05)$ indicates statistically significant difference from $\mathrm{kl}^{\%}$ mice (unpaired t-test).

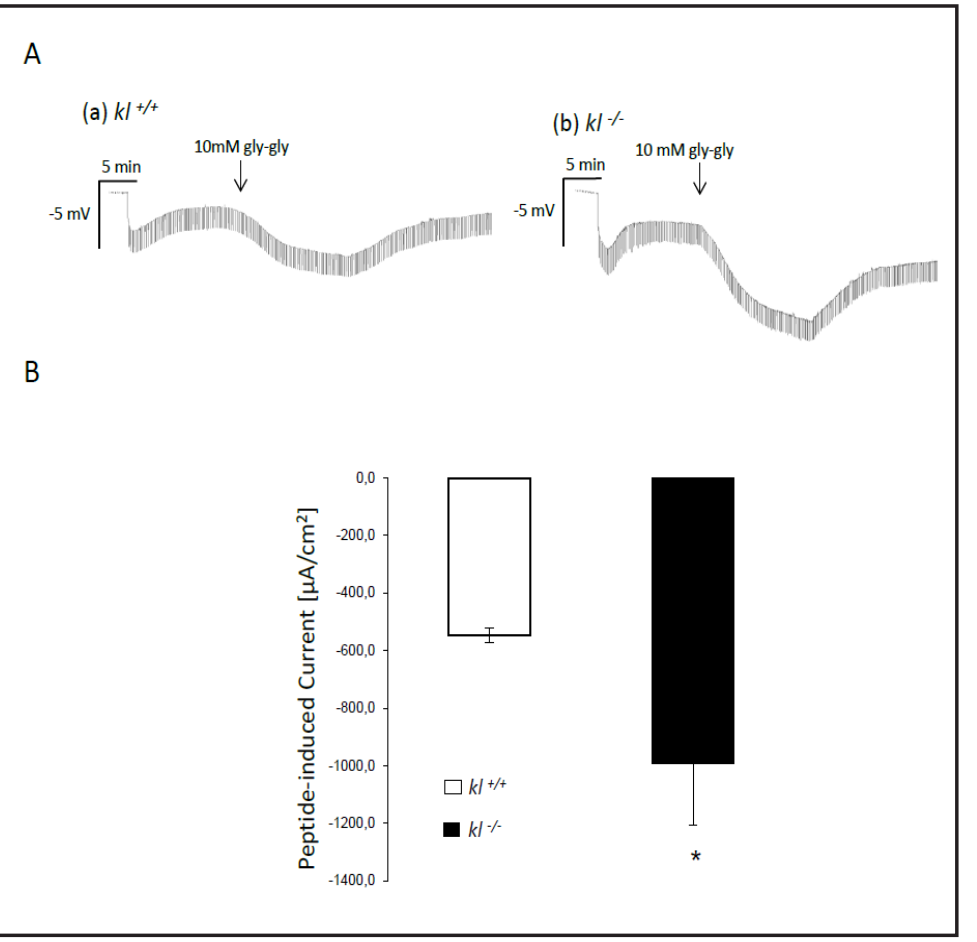

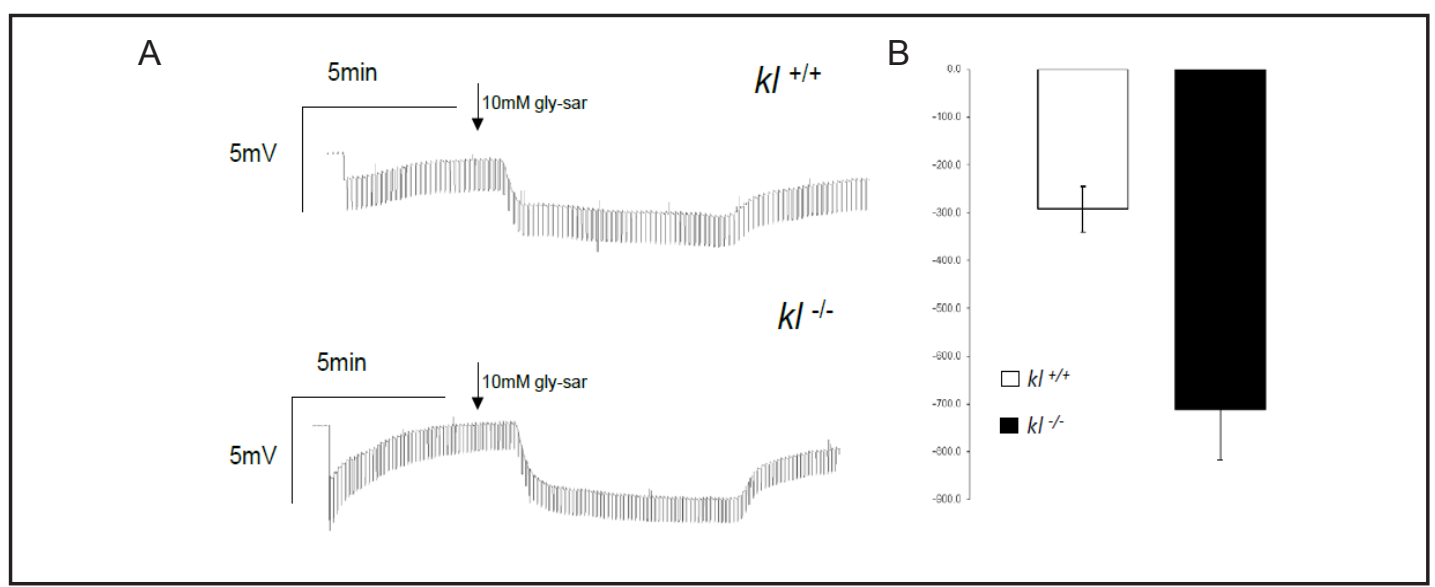

Fig. 6. Glycine-Sar induced transepithelial current in intestinal epithelia from klotho-deficient mice $\left(\mathrm{kl}^{/ /}\right)$ and wild-type $\left(\mathrm{kl}^{+/+}\right)$mice. A. Representative original tracings showing the effect of glycine-sar (gly-sar) (10 $\mathrm{mM}$ ) on the transepithelial intestinal potential difference in wild-type mice (Upper) and klotho-deficient mice (Lower). Arrows highlight the addition of $10 \mathrm{mM}$ gly-Sar. B. Arithmetic means \pm SEM ( $=3-4)$ of the gly-sar (10mM) induced equivalent short-circuit current across intestinal epithelium from wild-type mice (white bar) and klotho-deficient mice (black bar). ${ }^{*}(p<0.05)$ indicates statistically significant difference from $\mathrm{kl}^{\%}$ mice (unpaired t-test).

glycine-induced inward current $\left(\mathrm{I}_{\mathrm{Gy}}\right)$. Kinetic analysis revealed that $\beta$-Klotho was in large part effective by decreasing the maximal transport rate of the carriers. The large scatter of the calculated concentrations required for half maximal current precludes safe conclusions about effects of klotho on carrier affinity. The effect of $\beta$-Klotho on $\mathrm{I}_{\text {Gly }}$ was reversed in the presence of the $\beta$-glucuronidase inhibitor D-saccharic acid 1,4-lactone monohydrate DSAL. Thus, $\beta$-klotho was apparently effective as $\beta$-glucuronidase. Klotho belongs to the $\beta$-glycosidase family [49]. Klotho has previously been shown to hydrolyze extracellular sugar residues of target membrane proteins [49]. As shown for the epithelial $\mathrm{Ca}^{2+}$ channel TRPV5 [49] and the excitatory amino acid transporters [28], klotho may stabilize the transport 
proteins in the cell membrane. In contrast to its effect on TRPV5 and excitatory amino acid transporters, klotho down-regulates the peptide carriers. The present observations do not rule out that klotho modifies peptide transport in PEPT1 or PEPT2 expressing oocytes by mechanisms other than $\beta$-glucuronidase activity and other than destabilization of the carrier proteins in the cell membrane. Whatever mechanism involved, the effect of klotho obviously affects intestinal peptide transport. Presumably due to lacking down-regulation by klotho of peptide transporters, the peptide transport was markedly enhanced in klotho deficient mice. We can, however, not rule out the involvement of more indirect mechanisms modifying peptide transport in klotho deficient mice.

In view of the impact of peptide transporters on ageing [32], it is tempting to speculate that the down-regulation of intestinal peptide transport contributes to the impact of klotho on ageing. Even though up-regulation of peptide transporters is expected to accelerate ageing [32], the dramatic acceleration of ageing in klotho deficient mice is, however, obviously in large part the result of deranged mineral metabolism and tissue calcification [19].

In conclusion, $\beta$-Klotho down-regulates the activity of the peptide transporters PEPT1 and PEPT2. The effect apparently modifies intestinal peptide transport and may contribute a small part to the impact of klotho on ageing.

\section{Acknowledgements}

The authors acknowledge the meticulous preparation of the manuscript by Lejla Subasic and technical support by Elfriede Faber. This study was supported by the Deutsche Forschungsgemeinschaft, GRK 1302, SFB 773 B4/A1, La 315/13-3, Open Access Publishing Fund of Tuebingen University and the EMBO Long Term Postdoctoral fellowship (ATLF 202013 to M.S.S).

\section{Disclosure Statement}

The authors of this manuscript state that they do not have any conflict of interests and nothing to disclose.

\section{References}

1 Takeshita K, Fujimori T, Kurotaki Y, Honjo H, Tsujikawa H, Yasui K, Lee JK, Kamiya K, Kitaichi K, Yamamoto K, Ito M, Kondo T, Iino S, Inden Y, Hirai M, Murohara T, Kodama I, Nabeshima Y: Sinoatrial node dysfunction and early unexpected death of mice with a defect of klotho gene expression. Circulation 2004;109:17761782.

2 Tsujikawa H, Kurotaki Y, Fujimori T, Fukuda K, Nabeshima Y: Klotho, a gene related to a syndrome resembling human premature aging, functions in a negative regulatory circuit of vitamin $\mathrm{D}$ endocrine system. Mol Endocrinol 2003;17:2393-2403.

3 Cha SK, Ortega B, Kurosu H, Rosenblatt KP, Kuro OM, Huang CL: Removal of sialic acid involving Klotho causes cell-surface retention of TRPV5 channel via binding to galectin-1. Proc Natl Acad Sci U S A 2008;105:9805-9810.

4 Hu MC, Shi M, Zhang J, Pastor J, Nakatani T, Lanske B, Razzaque MS, Rosenblatt KP, Baum MG, Kuro-o M, Moe OW: Klotho: a novel phosphaturic substance acting as an autocrine enzyme in the renal proximal tubule. FASEB J 2010;24:3438-3450.

5 Imura A, Iwano A, Tohyama O, Tsuji Y, Nozaki K, Hashimoto N, Fujimori T, Nabeshima Y: Secreted Klotho protein in sera and CSF: implication for post-translational cleavage in release of Klotho protein from cell membrane. FEBS Lett 2004;565:143-147. 


\section{Cellular Physiology Cell Physiol Biochem 2016;40:874-882 \begin{tabular}{l|l|l}
\hline DOI: 10.1159/000453146 & $\begin{array}{l}\text { C } 2016 \text { The Author(s). Published by S. Karger AG, Basel } \\
\text { www.karger.com/cpb }\end{array}$ \\
\hline Published online: December 07, 2016 Biochemistry
\end{tabular} \\ Abousaab et al.: Klotho Sensitivity of PEPT1 and PEPT2}

6 Leunissen EH, Nair AV, Bull C, Lefeber DJ, van Delft FL, Bindels RJ, Hoenderop JG: The epithelial calcium channel TRPV5 is regulated differentially by klotho and sialidase. J Biol Chem 2013;288:29238-29246.

7 Tohyama O, Imura A, Iwano A, Freund JN, Henrissat B, Fujimori T, Nabeshima Y: Klotho is a novel betaglucuronidase capable of hydrolyzing steroid beta-glucuronides. J Biol Chem 2004;279:9777-9784.

8 Kuro-o M: Klotho. Pflugers Arch 2010;459:333-343.

9 Kuro-o M, Matsumura Y, Aizawa H, Kawaguchi H, Suga T, Utsugi T, Ohyama Y, Kurabayashi M, Kaname T, Kume E, Iwasaki H, Iida A, Shiraki-lida T, Nishikawa S, Nagai R, Nabeshima YI: Mutation of the mouse klotho gene leads to a syndrome resembling ageing. Nature 1997;390:45-51.

10 Kuro-o M: Klotho. Pflugers Arch. 2010;459:333-343.

11 Abed M, Feger M, Alzoubi K, Pakladok T, Frauenfeld L, Geiger C, Towhid ST, Lang F: Sensitization of erythrocytes to suicidal erythrocyte death following water deprivation. Kidney Blood Press Res 2013;37:567-578.

12 Feger M, Fajol A, Lebedeva A, Meissner A, Michael D, Voelkl J, Alesutan I, Schleicher E, Reichetzeder C, Hocher B, Qadri SM, Lang F: Effect of carbon monoxide donor CORM-2 on vitamin D3 metabolism. Kidney Blood Press Res 2013;37:496-505.

13 Razzaque MS, Sitara D, Taguchi T, St-Arnaud R, Lanske B: Premature aging-like phenotype in fibroblast growth factor 23 null mice is a vitamin D-mediated process. FASEB J 2006;20:720-722.

14 Yoshida T, Fujimori T, Nabeshima Y: Mediation of unusually high concentrations of 1,25-dihydroxyvitamin D in homozygous klotho mutant mice by increased expression of renal 1alpha-hydroxylase gene. Endocrinology 2002;143:683-689.

15 Alesutan I, Feger M, Pakladok T, Mia S, Ahmed MS, Voelkl J, Lang F: 25-Hydroxyvitamin D3 1-alphahydroxylase-dependent stimulation of renal klotho expression by spironolactone. Kidney Blood Press Res 2013;37:475-487.

16 Ramasamy I: Recent advances in physiological calcium homeostasis. Clin Chem Lab Med 2006;44:237-273.

17 Segawa H, Yamanaka S, Ohno Y, Onitsuka A, Shiozawa K, Aranami F, Furutani J, Tomoe Y, Ito M, Kuwahata M, Imura A, Nabeshima Y, Miyamoto K: Correlation between hyperphosphatemia and type II Na-Pi cotransporter activity in klotho mice. Am J Physiol Renal Physiol 2007;292:F769-779.

18 Kuro-o M: Klotho as a regulator of fibroblast growth factor signaling and phosphate/calcium metabolism. Curr Opin Nephrol Hypertens 2006;15:437-441.

19 Ohnishi M, Nakatani T, Lanske B, Razzaque MS: Reversal of mineral ion homeostasis and soft-tissue calcification of klotho knockout mice by deletion of vitamin D 1alpha-hydroxylase. Kidney Int 2009;75:1166-1172.

20 Boros S, Bindels RJ, Hoenderop JG: Active $\mathrm{Ca}(2+)$ reabsorption in the connecting tubule. Pflugers Arch 2009;458:99-109.

21 Dermaku-Sopjani M, Sopjani M, Saxena A, Shojaiefard M, Bogatikov E, Alesutan I, Eichenmuller M, Lang F: Downregulation of NaPi-IIa and NaPi-IIb Na-coupled phosphate transporters by coexpression of Klotho. Cell Physiol Biochem 2011;28:251-258.

22 Sopjani M, Alesutan I, Dermaku-Sopjani M, Gu S, Zelenak C, Munoz C, Velic A, Foller M, Rosenblatt KP, Kuro-o M, Lang F: Regulation of the Na+/K+ ATPase by Klotho. FEBS Lett 2011;585:1759-1764.

23 Cha SK, Hu MC, Kurosu H, Kuro-o M, Moe O, Huang CL: Regulation of renal outer medullary potassium channel and renal K(+) excretion by Klotho. Mol Pharmacol 2009;76:38-46.

24 Almilaji A, Honisch S, Liu G, Elvira B, Ajay SS, Hosseinzadeh Z, Ahmed M, Munoz C, Sopjani M, Lang F: Regulation of the voltage gated K channel Kv1.3 by recombinant human klotho protein. Kidney Blood Press Res 2014;39:609-622.

25 Almilaji A, Pakladok T, Munoz C, Elvira B, Sopjani M, Lang F: Upregulation of KCNQ1/KCNE1 K+ channels by Klotho. Channels (Austin) 2014;8:222-229.

26 Almilaji A, Sopjani M, Elvira B, Borras J, Dermaku-Sopjani M, Munoz C, Warsi J, Lang UE, Lang F: Upregulation of the creatine transporter Slc6A8 by Klotho. Kidney Blood Press Res 2014;39:516-525.

27 Almilaji A, Munoz C, Pakladok T, Alesutan I, Feger M, Foller M, Lang UE, Shumilina E, Lang F: Klotho sensitivity of the neuronal excitatory amino acid transporters EAAT3 and EAAT4. PLoS One 2013;8:e70988.

28 Warsi J, Abousaab A, Lang F: Up-Regulation of Excitatory Amino Acid Transporters EAAT1 and EAAT2 by ss-Klotho. Neurosignals 2015;23:59-70. 


\section{Cellular Physiology Cell Physiol Biochem 2016;40:874-882 \begin{tabular}{l|l|l|}
\hline DOI: 10.1159/000453146 & $\begin{array}{l}\text { C } 2016 \text { The Author(s). Published by S. Karger AG, Basel } \\
\text { www.karger.com/cpb }\end{array}$ \\
\hline Published online: December 07, 2016
\end{tabular}}

Abousaab et al.: Klotho Sensitivity of PEPT1 and PEPT2

29 Ingersoll SA, Ayyadurai S, Charania MA, Laroui H, Yan Y, Merlin D: The role and pathophysiological relevance of membrane transporter PepT1 in intestinal inflammation and inflammatory bowel disease. Am J Physiol Gastrointest Liver Physiol 2012;302:G484-492.

30 Inoue M, Terada T, Okuda M, Inui K: Regulation of human peptide transporter 1 (PEPT1) in gastric cancer cells by anticancer drugs. Cancer Lett 2005;230:72-80.

31 Rubio-Aliaga I, Daniel H: Peptide transporters and their roles in physiological processes and drug disposition. Xenobiotica 2008;38:1022-1042.

32 Meissner B, Boll M, Daniel H, Baumeister R: Deletion of the intestinal peptide transporter affects insulin and TOR signaling in Caenorhabditis elegans. J Biol Chem 2004;279:36739-36745.

33 Warsi J, Dong L, Elvira B, Salker MS, Shumilina E, Hosseinzadeh Z, Lang F: SPAK dependent regulation of peptide transporters PEPT1 and PEPT2. Kidney Blood Press Res 2014;39:388-398.

34 Warsi J, Elvira B, Bissinger R, Shumilina E, Hosseinzadeh Z, Lang F: Downregulation of peptide transporters PEPT1 and PEPT2 by oxidative stress responsive kinase OSR1. Kidney Blood Press Res 2014;39:591-599.

35 Fezai M, Ahmed M, Hosseinzadeh Z, Elvira B, Lang F: SPAK and OSR1 Sensitive Kir2.1 K+ Channels. Neurosignals 2015;23:20-33.

36 Fezai M, Warsi J, Lang F: Regulation of the Na+,Cl- Coupled Creatine Transporter CreaT (SLC6A8) by the Janus Kinase JAK3. Neurosignals 2015;23:11-19.

37 Warsi J, Abousaab A, Fezai M, Elvira B, Lang F: Regulation of Voltage Gated K+ Channel KCNE1/KCNQ1 by the Janus Kinase JAK3. Cell Physiol Biochem 2015;37:2476-2485.

38 Warsi J, Fezai M, Fores M, Elvira B, Lang F: Up-Regulation of Voltage Gated K+ Channels Kv1.3 and Kv1.5 by Protein Kinase PKB/Akt. Cell Physiol Biochem 2015;37:2454-2463.

39 Elvira B, Warsi J, Fezai M, Munoz C, Lang F: SPAK and OSR1 Sensitive Cell Membrane Protein Abundance and Activity of KCNQ1/E1 K+ Channels. Cell Physiol Biochem 2015;37:2032-2042.

40 Fezai M, Elvira B, Warsi J, Ben-Attia M, Hosseinzadeh Z, Lang F: Up-Regulation of Intestinal Phosphate Transporter NaPi-IIb (SLC34A2) by the Kinases SPAK and OSR1. Kidney Blood Press Res 2015;40:555-564.

41 Hosseinzadeh Z, Honisch S, Schmid E, Jilani K, Szteyn K, Bhavsar S, Singh Y, Palmada M, Umbach AT, Shumilina E, Lang F: The Role of Janus Kinase 3 in the Regulation of $\mathrm{Na}(+) / \mathrm{K}(+)$ ATPase under Energy Depletion. Cell Physiol Biochem 2015;36:727-740.

42 Warsi J, Singh Y, Elvira B, Hosseinzadeh Z, Lang F: Regulation of Large Conductance Voltage-and Ca2+Activated K+ Channels by the Janus Kinase JAK3. Cell Physiol Biochem 2015;37:297-305.

43 Alesutan I, Voelkl J, Stockigt F, Mia S, Feger M, Primessnig U, Sopjani M, Munoz C, Borst O, Gawaz M, Pieske B, Metzler B, Heinzel F, Schrickel JW, Lang F: AMP-activated protein kinase alpha1 regulates cardiac gap junction protein connexin 43 and electrical remodeling following pressure overload. Cell Physiol Biochem 2015;35:406-418.

44 Fezai M, Elvira B, Borras J, Ben-Attia M, Hoseinzadeh Z, Lang F: Negative regulation of the creatine transporter SLC6A8 by SPAK and OSR1. Kidney Blood Press Res 2014;39:546-554.

45 Warsi J, Hosseinzadeh Z, Elvira B, Bissinger R, Shumilina E, Lang F: Regulation of ClC-2 activity by SPAK and OSR1. Kidney Blood Press Res 2014;39:378-387.

46 Elvira B, Munoz C, Borras J, Chen H, Warsi J, Ajay SS, Shumilina E, Lang F: SPAK and OSR1 dependent downregulation of murine renal outer medullary K channel ROMK1. Kidney Blood Press Res 2014;39:353-360.

47 Munoz C, Pakladok T, Almilaji A, Elvira B, Decher N, Shumilina E, Lang F: Up-regulation of Kir2.1 (KCNJ2) by the serum \& glucocorticoid inducible SGK3. Cell Physiol Biochem 2014;33:491-500.

48 Ahmed M, Salker MS, Elvira B, Umbach AT, Fakhri H, Saeed AM, Shumilina E, Hosseinzadeh Z, Lang F: SPAK Sensitive Regulation of the Epithelial Na Channel ENaC. Kidney Blood Press Res 2015;40:335-343.

49 Chang Q, Hoefs S, van der Kemp AW, Topala CN, Bindels RJ, Hoenderop JG: The beta-glucuronidase klotho hydrolyzes and activates the TRPV5 channel. Science 2005;310:490-493. 